\title{
Virginia Woolf Established a Strong Human Relationship Through Effective Characterization in her Novel, "To the Lighthouse"
}

\author{
Imam Alam Khan ${ }^{1}$ \\ ${ }^{1}$ King Abdulaziz University, Jeddah, Kingdom of Saudi Arabia \\ Correspondence: Imam Alam Khan, King Abdulaziz University, Jeddah, Kingdom of Saudi Arabia.
}

Received: May 8, 2018 Accepted: June 5, 2018 Online Published: August 22, 2018

doi:10.5539/ells.v8n3p6 URL: https://doi.org/10.5539/ells.v8n3p6

\begin{abstract}
"To the Lighthouse" is a famous and exceptional novel of Virginia Woolf. It was published in 1928. It is one of the most popular and the most striking novels by the novelist, because it makes easier reading. It is largely unique in its structure, and it reveals its maturity over the technique. The novel is known for its distinctive presentation of dimensional transitions. One of the greatest achievements of the novelist is that the technique of the stream of consciousness finds its way through the ordering of the materials in the novel. Its outward structure is really simple. The novel is an attempt to present a specific aim. A novel has always been a real as well as dynamic reproduction of the thoughts and feelings of the novelist. The novel discards the old authoritarian pattern in the family relationships, which is no longer operative in the society. Now, there is a new orientation of parent-child relationship as well as re-orientation of family and friends' relationships. That is the vision of life in the mind of the novelist. And, that is the aim of the writer. The novel's universal spirit and appeal will be under discourse in particular and the manifold visions in which what is receding and what is approaching, find ways to establishing a strong relationship with people in the novel. Therefore, this paper is going to investigate its realistic presentation of feelings and thoughts. It investigates that the novel exhibits the fluid mental states rather than external violent deeds. That the readers themselves interpret and then understand each of the vital characters through his or her own unique thoughts as well as through his or her specific actions. It could be called a novel of stream of consciousness, yet with a difference. Hence, the novel in question investigates its comprehensiveness in design, and "how visions have been presented for establishing relationships among the characters in the novel through strong characterization with a new technique".
\end{abstract}

Keywords: stream of consciousness, human relationship, human nature, characterization, intellect

\section{Introduction}

Robert Liddell has very precisely remarked, "Every writer should faithfully present himself before us". (Liddell, 1953, p. 93) So, let us examine the plot of the novel. The plot of the novel, "To the Lighthouse", is appropriately simple. The novel consists of three parts. The first part is called "The Window". This part of the novel introduces the main characters of the novel. It also tells about whether or not the planned expedition to the lighthouse will take place. This is the real and central issue of the novel. The issue has so nicely been introduced that the readers aptly know about the real lighthouse journey. However, it is not the obvious kind of interest which the readers think "what is going to happen next kind of interests. It, apparently, emphasizes how the events in the novel have been experienced by the characters who participate, and its narration is exceedingly carried out through the manifold point of view method. In addition, the reflections of human nature have certainly been the basis. The readers' attention as well as their access to the mental process of the different characters has been established through a new method of presentation. It is said about the novelist, Virginia Woolf, "She is bold enough to break the traditional way of novel writing and gives a new direction, a new vision and a new form to English fiction". (Prasad, 2004, p. 68) Mrs. Ramsey is greatly presented here as an uncompromising and lovable heroin of the novel. She appears to be a tyrant and pathetic character, though. This part of the novel is mainly presented through the consciousness of Mrs. Ramsey. She has been shown sitting by the window and knitting. Later she has been shown presiding over the dinner party. The second part, "Time Passes", covers a passage of ten-year time. It talks about the deaths of the members of the Ramsey family. This part of the novel depends mainly on the voices of the omniscient narrator. The third and the final part of the novel is named "To the Lighthouse". It tells the readers about Mr. Ramsey's arrival at the lighthouse with two of his children after ten years. It also tells 
about Lily's making the final stroke of her brush after having her vision at last. W. H. Hudson's remarks should be quoted here. His observations, "In the loose plot, the story is composed of a number of detached incidents". (Hudson, 2014, p. 139)

\section{Literature Review}

The present novel, "To the Lighthouse", is often considered the most successful novel of Virginia Woolf. To have a vivid look on the literature review of the novel, it would begin with that the novel itself incorporates an image in two ways. It is a place where the characters of the novel will arrive, and plays the role of a source of light to guide. This incorporates a very much symbolic vision. To understand life and its courses, the vision in the image of the Lighthouse seems very significant. Virginia Woolf, as a novelist, thinks that the novel is a means to the patronizing end, and it aims at exploring the facets of the soul. She tries to present the picture of life as she has experienced it, yet through her own vision of life. She chooses novels as a means of communication. However, she differs from the materialists or even naturalists in regard of beauty. She also differs from even Emile Zola. She appears to me as a contemplative fiction writer because aesthetic experiences are contemplative affairs. That is the reason why we find her characters so lonely. However, their relations with others preserve utmost connotation with them to enrich their inner life. Again, I can say that contemplation is a lonely affair. Satish Kumar feels, "To the Lighthouse studies the relationships of the members of the Ramsey family with great artistic unity". (Kumar, 2008, p. 488)

The pattern of narration as well as events goes side by side in the novel. The small and random events have been given more importance to reveal the significance of life and the human relationship. The random events such as "measuring the stocking", "a conversation with the maid", "a telephone call", or "throwing of the mutilated fish into the sea" show the importance of the human-relationship. The tragic deaths of Prue Ramsey and Andrew Ramsey are announced like random events.

"[Prue Ramsey died that summer in some illness connected with child-birth, which was indeed a tragedy, people said. They said nobody deserved happiness more.]"

And this about Andrew:

"[A shell exploded. Twenty or thirty young men were blown up in France, among them Andrew Ramsey, whose death, mercifully, was instantaneous]".

The novelist, Virginia Woolf, tries to reveal the importance of human relationship through the events. She presents them as trivial events, yet they create longer impressions. Sometimes they suggest the adequacy of and its maturity. The other times, they signify the inadequacy of human relationship. Such types of revelation of the events were not familiar in England. They were revealed in the works of Marcel Proust's of France and Hamsun of Norway. The novelist presents the random events, or minor happenings which are insignificant as exterior factors in a person's destiny, yet they are important for the development of the motives in the novel. They could work as penetration which open up new prospective into a milieu. Terry Eagleton remarks, "And, since all impressions, whether trifling or momentous, have in common the fact that they are impressions, they have the effect of levelling hierarchies of value". (Eagleton, 2005, p. 316)

The novelist, Virginia Woolf, has been keenly observed by the readers as well as the critics. And, it has been established that the novelist has been driven throughout her life by her own, unique and accepted vision of life. She emphasizes it through the different kinds of personalities in her novels with variabilities in the personalities of the characters. And, this variability is the characteristic of her novels. All the characters of the novel in question show the perceived variabilities in the personalities of the characters. They all have different personalities, and they all behave in different ways and manners. This ever changing consciousness in the personalities keeps the novel running and the readers go on reading words by words and pages after pages until they finish it and start thinking about the novel. They never experience any fixity in the whole novel, for it establishes a human bond, a real life-experience, its continuity as well as its fluidity. Katherine Lever's point of view about a novel can be cited here to prove the world of the novelist. She writes, "The novel may be defined then as the form of written prose narrative of considerable length involving the reader in an imagined real world which is new because it has been created by the author". (Lever, p. 27) Therefore, it is clear that the visions in the novel play the vital characters to create the significance of life and the people around us. 


\section{Discussion}

The novel is remarkably unique in the sense that its effective characterization is certainly in line with the plot construction which very much echoes the stream of consciousness technique. It presents vision of life, which is in all respect larger than art. The novel's first part, "the Window" represents life. And, Mrs. Ramsey's character represents it in full. That's why, the novel open with Mrs. Ramsey. This means life, the character, provides life. The stuff of life seemingly converts into the work of art through a medium. The other thing is that Lily Briscoe closes the novel. It means that Lily represents art. Here, it is very important to note that if life and art are taken as opposites in the novel, Mrs. Ramsey and Lily Briscoe could be regarded as their respective exponents. That's why the first part of the novel which represents life is larger than that of the third part which represents art. Mrs. Ramsey personifies the life, and that's why she is the central character of the novel. She is the subject of Lily's painting, and it gets the final touch at the end of the novel. Hence, the novel represents a relation between the characters whether they are devoid of verbal communication. The character of Mrs. Ramsey is the subject itself as well as a gradual formation of the character. Robert Liddell says, "the subject of a novel is often, in itself, a gradual process - the gradual formation, for example, a character". (Liddell, 1953, p. 58)

Almost all the characters in the novel, "To the Lighthouse", are lively as well as self-motivated. They have their own identity. The ordinary readers can never reach the psychological significance of the characters. The author, Virginia Woolf, intelligently takes the readers into the psyche of the characters, and she shows chaotic movements, sensations as well as the impressions felt by the minds of the characters. This way, the readers are taken to the very close to the characters. She has created a lot of memorable and vivid characters. She has created round characters, too. "They are personal and metaphysical". (Eagleton, 2005, p. 322) We feel the physical presence of Mrs. Ramsay in the first part of the novel. Then she is no more. Even then, she encompasses the whole novel. Her influence on the other characters, especially on Lily Briscoe, is great. Mr. Ramsay is a character who has superb intellect with deep philosophical dispositions. He has a bold, fascinating, but a complex personality. Lily Briscoe's imagination is really visual. Her fancy is pictorial. However, as she dipped into the blue paint, she dipped too into the past. She begins to lose consciousness as well as memories. Later, she feels better. Thus, the features of the characters of the novel remarkably move as the narration moves forward. "A novel is the reflection of human nature. Human nature, on the other hand, is endless and unfathomable. So, we can't give a very hard and fast shape to a novel". (Prasad, 2004, p. 31) So, the novel is going to be tested on the impacts it carries even today.

The characters apparently seem individuals, yet they distinctly appear as types. The character of Mrs. Ramsay is the central figure around which actions and movements have been put together. Right from the very beginning of the novel, she appears to be structurally as well as psychologically a cohesive force. Hence, she is the source of unity in the novel, and she holds almost all characters, major or minors, as well as the actions, movements and all incidents in the novel. Having a terrific intellect and a deep philosophical disposition, Mr. Ramsay appears to be complex character, fascinating everyone with his bold veins. He is one of the most dominating characters of the modern literary age. Lily is the character whose last stroke of her painting concludes the novel. And, this last stroke happens with the arrival at the lighthouse. Obviously, both the completions mean to happen together is very much remarkable. Lily is also a character with vision. Simple, yet she is difficult with her vision, gets her vision into reality with the last stroke of her brush. And, that's what she is. G. S. Frazer rightly observes, "She (Virginia Woolf) offers us a lyrical abstraction from the pain with which she felt the world; the quality of her mind and spirit has a distinction that will make some readers always grateful to accept the offering". (Frazer, 1976, p. 721)

In the conventional nineteenth-century novels, characters were portrayed and presented through their words and then by their actions as well as through the judgment of other characters. They were judged through the overt as well as covert conclusions by the chronicler. But, this novelist tries to depict the nature of the major characters in the novel. The novel radically presents commentary on the meaning of the human nature. That is the very form of the novel, "To the Lighthouse". The human relationships have been erected on the very opposite adjectives which form the combinations. They are loving, yet reserved. They are selfish. However, they are generous. They appear to be cold, but passionate. Look at the various characters of the novel, "Mrs. Ramsay and Mr. Ramsay", "Lily Briscoe and Mr. Bankes", "Paul Reyley" and "Minta Doype" and so on and so forth. And all other characters of the novel are responsible for a new form as well as very much unique quality of the characterization. Hudson holds the view, "She herself aimed at something finer that would convey the essences of human life". (Hudson, 2014, p. 300)

The readers' impressions of all characters are cumulative and developing from the many versions of a character shown by the different reporter. In this way, the reader is made free finally to create his own single as well as 
unified account of the novel's characters from the manifold previews, which the novel meets the value of the uniqueness of the characterization. The convention of plot, tragedy, comedy, climax, anticlimax, and catastrophe has been disregarded by the novelists of the school of stream of consciousness. And, Virginia Woolf is one of them. The novelist tries to depict the conception of human experience as well as the continuity and fluidity which have been emphasized critically as well as beautifully. Arnold Kettle, a well-known critic, writes and holds the view, "at the same time, the good novel doesn't simply convey life: it says something about life; it reveals some kind of pattern in life. It brings significance". (Kettle, 1967, p. 13) I think, the above view of the critic supports the investigation.

"To the Lighthouse" is, by and large, a novel based on the modern technique of the stream of consciousness and hence, it is a shift from the conventional novel writing. Individual is more important than society. The novelist tries to peep into the various types of personalities and their inner nature of the characters, rather than peeping into the social customs and norms. One soul is an individual one. It never merges with another soul. One personality never combines with another one. Therefore, the modern novelist like Virginia Woolf comes up with the theme where relationship between individuals is more important, rather than the morality, or refinement of the society. Such is the case with the present novel. It values individual's love, loneliness, patience, care and other inner feelings of human nature. It has the subject matter of the consciousness of almost all the characters in the novel. In the present novel, readers find Mrs. Ramsay, the protagonist, very much a lonely figure. She is important because her inner life is important for her. Her relationship with other characters in the novel is significant to her who enriches the beauty of her life as well as the beauty of the novel. And, so is the case with Lily Briscoe. She appears to be the same lonely figure. And, so are the cases with other characters in the novel. The novelist tries to create the need to use the memories of the characters in place of the readers' in a relationship with the past, where the novelist herself takes a break and goes away from the scene. And, that's the significant shift in the narrative of the novel, which proves that the fiction for the novelist, Virginia Woolf, is not a "criticism of life", rather it is a recreation of the complexities of human experience, which makes it the most subtle as well as supple in order to catch the "tones", "light" and "shades of experience". Terry Eagleton remarks in his book, "The English Novel: An Introduction", "What imposes unity on this flux-impressions is art. Art is what orders experience into significant design". (Terry, 2005, p. 311) And, that's the novel here imprints the novelist's unity as well as perception of the experience of the human relationship through the subtle delineation of the characters in the novel.

"To the Lighthouse", is certainly a "stream of consciousness" novel without any doubt. However, it is a novel of the modern technique, "streams of consciousness" with a difference. The novelist, Virginia Woolf, has been found very much careful while uniting the characters' consciousness together, and with one character's view on another. And, the effective use of the characterization has been finely organized as well as the theory of fiction has been agreeably revealed. Virginia Woolf has her own vision as well as her own opinion about fiction. She says, "life is not a series of gig lamps symmetrically arranged; life is a luminous halo, a semitransparent envelope surrounding us from the beginning of consciousness to the end". The very word, "consciousness" gives rise to the idea of the whole novel. She adopts a very much new technique, rejecting the conventional one, to express her own vision of life. She neither wished to be a materialist like H. G. Wells, nor like Arnold Bennett. She, nor wanted to be spiritualists like James Joyce and Marcel Proust. She realizes that the most significant item for a novelist is to comprehend the different impressions, which the mind or soul of the characters' experience in their general ordinary lives, and then expresses them through the art of fiction. W. H. Hudson observes in his famous book and writes, "Literature is a creative art, written by creative literary artists. The motive power of artists is imagination, which endows them with vision and the perception of truth in its full aspects". (Hudson, 2014, p. 291)

And, the most important thing, about the technique of the stream of consciousness novels, is that such novels have mainly as their essential subject-matter the consciousness of one or more characters. The readers come across the interior monologues and experience the fluid mental states, which exist simultaneously as well as numerously in an individual's entire existence. Thus, the representations of the consciousness of Mrs. Ramsay, in the novel, make us comprehend the true character of Mrs. Ramsay herself and of course, the characters of Mr. Ramsay, Lily Briscoe and then that of Charles Tansley. Similarly, Lily Briscoe's stream of consciousness reveals the personality as well as the finer and different shades of the characters of Mrs. Ramsay and Mr. Ramsay. It enables us to comprehend the odd as well as the unstable personality of Charles Tansley. It is finely observed by Terry Eagleton, "she invents a form of writing which shifts attention from this deceptively self-sufficient entity to much more fluid, fragile, borderless thing known as the subject". (Eagleton, 2005, p. 319) 
Characterization happens to be the most significant element of a novel. It is the mighty pillar on which the edifice of the novel is erected. It plays a vital role in the novels of stream of consciousness. It is very important because the emphasis in the stream of consciousness novels is constructed on the inner being of the characters rather than the outer social milieu. Sigmund Freud, Carl Gustav Jung, William Mc Dougall and William James unlocked the maze of the human perceptions. The novelists like Proust and Bergson started peeping into the dark recesses of the human mind, and followed by Henry James and Conrad. Thereafter, James Joyce tried his best to read the inner beings of human brain and presented marvelous novels like; "Portrait of an Artist as a Young Man" and the epic novel, "Ulysses". William Faulkner and D. H. Lawrence tried to study the human minds and presented stream of consciousness novels. Virginia Woolf started her stream of consciousness novels with "Jacob's Room". However, the technique finds its culmination in her perfect novel, "To the Lighthouse".

Virginia Woolf, the novelist of stream of consciousness technique, appears paying attention to the inner mayhem going on in the mind of her protagonists. Anita Desai, one of the finest novelists of India, seems to have the same idea about the stream of consciousness novels. She applied the same technique in almost all her novels. R K Dhawan quotes about Anita Desai in his book, The Indian Women Novelists, "He can only feel this way by intuition. Intuition is always silent. And, he must have the critical sense to know when something threatens to cloud his vision, to sully it". Mrs. Desai, a great Indian novelist of International repute, got impressed by the writings of Virginia Woolf. Under her influence, she started writing novels and adopted the same technique. Her first novel, Cry, the Peacock, published in 1963, showed the same outstanding sensibility of the inner actions rather than the queer world of actions. She is one of the greatest admirers of Virginia Woolf as a novelist. She liked her style and technique so much that she used the same stream of consciousness technique in first novel, "Cry, The Peacock", and later in her second novel, "Voices in the City". Both the novels are wonderful. And, she used the same technique in her other novels, too.

Let us examine the role of Mrs. Ramsay in "To the Lighthouse". She is the most vital character of the novel around which all characters, even events revolve. She, happens to be the centre around which all actions as well as movements have been structured, plays the most significant role. She has been a cohesive force which holds all the characters and incidents together in this great novel. She dominates the novel not only during her life, but even after her death. The opening scene is very important in the novel. The readers find the focus on Mrs. Ramsay. She appears to be as a model for Lily Briscoe. She is sitting at the window. It links the lawn with that of the interior of the window. People start coming and going. However, she apparently appears to like a milestone in the movements of different characters. The character of Mrs. Ramsay follows the character of Mrs. Dalloway. Mrs. Dalloway's character leaves an imprint on the minds of the readers. It was a natural and perfect character. However, Mrs. Ramsay's is considered to be, in many ways, the most popular character, because it makes the reading of the novel easier and it shows more maturity. Terry Eagleton holds the view about Mrs. Ramsay, "The charismatic Mrs. Ramsay is herself a kind of maternal artist. She is a skilled creator of harmonies, a domestic negotiator who reconciles the contentions around her by her radiant resourcefulness of being. Like a work of art, she integrates unruly elements". (Eagleton, 2005, p. 323)

It has been observed that almost all novelists create their personal visions which they collect, or gather, from their daily lives. And, that is the case with Virginia Woolf, too. In this novel, with the characterization of Mrs. Ramsay, or Mr. Ramsay, she has done the same thing. She has expressed her vision of life through her characters. Walter Allen holds the view, "A novelist is a totality, ... . Of this totality, characterization is only a part, yet it is plainly an essential one and the first in order of importance". (Allen, 1954, p. XVIII) The portrayal of Mrs. Ramsay is the same like the imagination of the readers. The most outstanding attribute of Mrs. Ramsay's figure is her compassionate character. She has been kind to the poor as well as compassionate for the unfortunate. She appears to have great concern as well as considerations for the children. She finds infinite sympathy for neglected souls, and thinks to bring happiness to the unhappy. She even goes to the town to help the needy and the poor. Thus, the traits of a single character, Mrs. Ramsay, establish a very much core relationship among characters in the novel overtly, and bind people in the family covertly. E. M. Forster's remark is really satisfying to prove the character of Mrs. Ramsay, "Individualism is a most valuable quality". (Forster, 1968, p. 86) The novelist has tried to reveal by the displaying the character of Mrs. Ramsay that it is Mrs. Ramsay's individualism which really controls the union in the novel. She possesses all the good qualities of a good person as well as she is a weak character who owns some of the flaws of a protagonist. Therefore, it is established that the character of Mrs. Ramsay is right at the end of the novel. She dominates the novel even after her death. And, her "lies" are proved to be the truth very much refutes Mr. Ramsay's facts. Time passes but true time can never pass. It is the apparition of Mrs. Ramsay's at the same window which enables Lily Briscoe to complete her picture. 
Mr. Ramsay and Mr. Charles Tansley are the first to visit Mrs. Ramsay. Here, it is very important to state that Mrs. Ramsay's impressions about the people, who came across her, have been shown through her stream of consciousness; fill out the scene for the readers. Then come Mr. Bankes and Lily Briscoe. They are also within her vision. Hence, she is the centre around which all characters appear moving. All the different characters in the novel with different ideas as well as with their eccentricities are seen held together by the great tactfulness, sympathy and her understanding. She has been found a unifying as well as a cohesive force during the dinner party. Here, she very nicely performs the duty of connecting different characters to one another, or each other. The examples of this can be found in the relationship of Lily Briscoe and Mr. Charles Tansley, and many other characters which develop later in the novel. She has been a beauty and charm incarnate throughout the novels. Though, she is the mother of eight children, yet her attractiveness of physical charm gets appreciation. The beauty of Mrs. Ramsay holds the people together. A relationship is created among the male and female characters in the novel. The other traits of her personality are her grace, dignity and her influence over people. She appears to be polite, cultured, full of manners and a symbol of female principles. She is kind and sympathetic. However, she is susceptible to flattery. Nevertheless, she wishes that men and women should unite and become fruitful, like her. W. H. Hudson remarks, "all Virginia Woolf's characters are aspects of herself". (Hudson, 2014, p. 300)

"To the Lighthouse" comprehends symbolic suggestions. The word symbolism means the discussion of an object refers to another demanding attention also in its own right, as well as pointing towards another object of an area of experience. And, the novel apparently seems full of symbols and symbolic suggestions. Symbolism, in general, is the presentation of ideas, moods and objects through the medium of emblems, or symbols. And, I think, it would be impossible to trace them here and there in the novel. The symbolism could be assessed to create a deeper sense about the novel and to convey the meaning. Because, the development of the novel and the development of each character apparently has been associated with the symbolism. Virtually, the core of the novel's world holds the very essence of symbolism. And, the significance of the novel has been created through the novel's symbolic structure, which drives the story further and pushes the immediate reference of characters as well as the story on to the general level. The bond among the characters represents the common human experience. It is what that emboldens them to encounter against time, death as well as against other celestial forces, which forever threaten to destroy man. The symbolic materials have been so carefully, psychologically and realistically interwoven that it seems injustice to separate them from the novel. One of the writers claims that, "To the Lighthouse" is often considered her most successful work which deals symbolically with time and art and attempts to echo the scattered conversation and random thoughts that occur in the minds of several of the characters". (Prasad, 2004, p. 69)

The various symbolic patterns are hereunder. The images, which Virginia Woolf uses in the novel, are vital, creative and illustrative. "The window" is the title of the first part of the novel, and it symbolizes the very imperfection of our knowledge. As it is a separating sheet of glass between the reality and Mrs. Ramsay's mind. We find that it is in the heart of darkness that Clarissa's world in "Mrs. Dalloway" and that of Mrs. Ramsay's in "To the Lighthouse" take one meaning through the image used. The images in the symbolism of colors have more effect on readers when they find different colors denoting or symbolizing very deep meanings. Mrs. Ramsay who appears as a triangle purple shape, while Lily Briscoe's painting appear as bright violet and staring white show some connotative meanings. Mr. Ramsay, who visualizes glimmering red color for his unattainable philosophy, shows his egotistical nature. The colors for Lily Briscoe as well as for Mr. Ramsay apparently indicate a journey. For Lily, it is a journey from personal to impersonal, and the journey of Mr. Ramsay appears to be from egotism to impersonality. The characters have been arranged in their relationship so carefully that a definite symbolical pattern emerges where suggestions can be interpretative. Therefore, the discussion reveals to us that the theme of the novel, "To the Lighthouse", is certainly symbolic in its association. The framework of the novel appears to be very simple. However, Virginia Woolf has tried to weave a delicate pattern of symbolic characters as well as situations, and she is certainly successful in her suggestion. Dr. Raghukul Tilak says, "But, Virginia Woolf, like a poet, frequently uses images to express her ideas. Objects and ideas evoke images in her mind automatically as they do in the mind of a poet". (Tilak, 1992, p. 151)

Take a look at the very title of the novel "To the Lighthouse". As a matter of fact, it is very much suggestive in its own way. As the title suggests, and as Virginia Woolf acknowledges in her letter to Roger Fry, is the central symbol of the novel. It is certainly connected with many images. It is associated with images of light as well as with darkness, which occur recurrently in the novel. Mrs. Ramsay associates herself with light, while Mr. Ramsay is connected with darkness which is again associated with compassion and understanding, and the egotism of Mr. Ramsay gives way to impersonality. And, Virginia Woolf has made extensive use of symbols in 
her novels, including "To the Lighthouse". It is a known fact that imagery permeates throughout the novel, and symbolism pervades the whole of the novel. The very title of the novel is very much symbolic as well as allusive. The lighthouse itself is very much important as symbol as well as very much expressive. It apparently appears engaged actively in time, movement and change. And change is life itself. It reveals "the moment" in its vibrant interaction between consciousness and the world. Therefore, establishing a human relationship is the basis of the novel through the uses of symbols as well as through the adoption of the stream of consciousness technique in the novel.

Virginia Woolf published three novels in her middle phase of novel-writing. "Jacob's Room" was published in 1922, "Mrs. Dalloway" came in 1925 and "To the Lighthouse" was published in 1928. It appears by certain features of "Jacob's Room" that the novelist is on the way to implement the "stream of consciousness" technique in her novels of future. There is a little of story interest in "Jacob's Room". However, Virginia Woolf appears to be concentrated on the "inner life" of Jacob Flanders. The remarkable use of the "stream of consciousness" technique is again adopted with a success. However, "the stream of consciousness technique" gets its culmination in "To the Lighthouse" where the highest level of success is achieved. It reveals greater maturity, and greater command over technique is achieved. It appears to be a great work of art. The novel permits the novelist to send a message of a certain and intimate quality of felt-life. And, it is done with a wonderful precision. In this novel, the resulting whole has been finely organized and in a more effective manner.

The journey in the novel, from the start of the book till its end, is the journey to the Lighthouse. It has three phases. The three phases of the journey which is called, "The Window", "Time Passes" and "The Lighthouse" respectively, epitomize alternating period of light and dark in the life of the Ramsay family. The character of Mrs. Ramsay is obviously the vital one in the family, as well as in the novel. Therefore, the pattern of the lighthouse beams, structurally, with its rhythmic steady flashes through the darkness form. And, a basic pattern of the novel evolves itself. The last two actions, "arrival at the lighthouse and the last stroke of the brush" are very important. They complete and the completeness of life or a journey completes. Therefore, they happen together. The threefold form of the novel, where the third phase returns to the first, is a basic form in music. It is the pattern of the music which has the rhythmic appropriateness, must have been the novelist's ideal of her novel enclosing her subject, or forming a circle. Virginia Woolf says of the novel, "To the Lighthouse", in her diary: "I feel as if it fetched its circle pretty completely this time".

The novel, "To the Lighthouse", should be read with a conception that it deals with a perceptible vision, works its way through it on the three perceptible levels - human relations, metaphysics and aesthetics. The human relations go side by side with every action and movement of Mrs. Ramsay. It also goes through the incidents of the novel. The novel deals with how the knower looks at the known, how one person looks at another, how man looks at nature and how the artist looks at life. There are three specific ways of seeing the object in the novel: through the eyes of the artist (Lily), through the eyes of a child (James), and through the eyes of the central figure who is a feminine, creative and solid like a poet character in the novel. They see the things, they see themselves and they see the world, yet they all see them differently. However, they very often bring the objective world into subjective consciousness. And that's the real vision of the novelist in the novel, "To the Lighthouse". It is better to submit some lines from W. H. Hudson's book in support of the investigation. He writes, "the unity of the narrative depending not on the machinery of the action, but upon the person of the hero, who, as the central figure or nucleus, binds the otherwise scattered elements together". (Hudson, 2014, p. 139)

The novelist has tried to establish different forms of relationships among the characters of the novel, "To the Lighthouse". The fictional characters, whose endeavors with different types of success, happy and wealthy relationship with the people around them, play vital roles in establishing satisfactory harmony. The relationship is very much congenial in nature. It is emotions, and emotional understanding with a genuine sympathetic attitude is required abundantly. The relationship between Mrs. Ramsay with Mr. Ramsay, though not very mature, yet it is based on real emotional understanding. And this is a really healthy, satisfactory relationship between a husband and wife. This is a very touching element of the novel. Satish Kumar holds the view, "It (To the Lighthouse) studies the relationships of the members of Ramsay family with great artistic unity than is found in her previous novels". (Kumar, 2008, p. 488) The relationship between Mrs. Ramsay and her children is another emotional and real one. The relationship between Lily Briscoe and Mr. Bankes, Paul and Minta, as well as all other characters and among themselves is remarkable. All the relationship in the novel can be justified to suit the polite and social fabrics of the novel. The very first movement of the novel, "The Window", shows the patterns of the relationship among the characters which have been woven skillfully from one extreme to another. It is something like someone who suffers and the mind which creates. Here, the character of Mrs. Ramsay, in "To the Lighthouse", especially, suffers and the novelist, Virginia Woolf, creates. The characterization in the 
novel is through the visions of the novelist. It is something visible, yet partly invisible. And, thus, the readers are made to visualize their own selves in the character of the novel. It is possible only when the novelist gives away his personal oddities and eccentricities and, "compose his difference with as many of his fellows as possible, in the common pursuit of true judgment" (Eliot, 1974, p. 21)

\section{Conclusion}

The novel, "To the Lighthouse", effectively presents a solid foundation of characterization. The foundation of a new technique has been laid gradually developing in the previous novels. It has reached a little height in "Jacob's Room". It finds the culmination of the new technique, "stream of consciousness", in this very novel, where characterization finds its self-reliance. It shows a greater mastery of the stream of consciousness technique. It studies the relationships of the members of the Ramsay family with great artistic unity". (Kumar, 2008, p. 488) The characterization in the novel has been so skillfully woven that its impact of one personality upon another continues throughout the novel. It creates a portrait of a complete human being which gives satisfaction to the readers. Mrs. Ramsay is one of the most ideal characters and so is the character of Mr. Ramsay. He appears as a full human being in his flesh and body. Lily Briscoe appears as full human being with intelligence as well as with her negative ideas. She completes herself with her last stroke on her painting. However, the characterization has not been drawn in outline. Virginia Woolf does not believe in a definable character. She doesn't want to create an illusion about her characters. The character, which establishes the relationships among the members of her family as well as the members of the people around her, is really remarkable. It is she who makes them reconcile their contentions in a very easy way. It is so simple for her. She plays maternal character, in one way or the other. To support that the relationships have been usually supported and made into a strong bond by Mrs. Ramsay, I would like to present the view from the wonderful book of Terry Eagleton where he writes, "Like Emma Woodhouse, she also "composes" rather too freely, plotting possible relationships for her companions". (Eagleton, 2005, p. 323)

Human nature has been emphasized rather than definition, or some kinds of boundaries. Hence, this novel definitely has a form and pattern with some inner unity. It is a great novel with satisfied and justified characterization. Through the characterization, the novelist has succeeded in establishing a vital relationship among the characters with life as well as with art, too. In fact, Virginia Woolf is a great novelist, who experiments the new technique of stream of consciousness with great success. The following lines of W. H. Hudson will be sufficient to quote in support of the research, "composed of a number of detached incidents, having little necessary or logical connection among themselves; the unity of the narrative depending not on the machinery of the action, but upon the person of the hero, who, as the central figure or nucleus, binds the otherwise scattered elements together". (Hudson, 2014, p. 139) Finally, it could be suggested that the topics in the title have been investigated and defended well with reasons on rational lines and have proved that the research is acceptable, defensible and very much satisfactory. The novel has great impacts on the readers. It influences the readers in the same way as it did when it was published. It is really a great novel for all time.

\section{References}

Allen, W. (1954). The English Novel. New York: E P Dutton \& Co. Inc.

Dhawan, R. K. (1991). The Indian Writer's Problem, Indian Women Novelists (Vol. 2, p. 8).

Eagleton, T. (2005). The English Novel: An Introduction. New Delhi: Blackwell Publishing, Wiley India Pvt. Ltd.

Eliot, T. S. (1974). Three Essay. Edited by Shiv K Kumar. Delhi: OUP.

Forster, E. M. (1968). Aspects of the Novel. New Delhi: Penguin Books, India Pvt. Ltd.

Frazer, G. S. (1976). Quoted by Raghukul Tilak: Literary and Social History of England. Rajhans Prakashan Mandir, Meerut, India.

Hudson, W. H. (2014). An Introduction to the Study of Literature. New Delhi: Kalyani Publishers.

Kettle, A. (1967). An Introduction to the English Novel. New Delhi: Universal Book.

Kumar, S. (2008). A History of English Literature. Agra: LN Agarwal Educational Press.

Lever, C. (1961). The Novel and the Readers. London: Methuen \& Co. Ltd.

Liddell, R. (1953). Some Principles of Fiction. Jonathan Cape, Thirty Bedford Square, London.

Prasad, A. N. (2004). Arundhati Roy's The God of Small Things: A Critical Appraisal. New Delhi: Sarup and Sons. 
Tilak, R. (1992). A Short History of English Prose and Essays. Bareilly, India: Prakash Book Depot.

\section{Copyrights}

Copyright for this article is retained by the author, with first publication rights granted to the journal.

This is an open-access article distributed under the terms and conditions of the Creative Commons Attribution license (http://creativecommons.org/licenses/by/4.0/). 